\title{
El recuento ("Der Appell")
}

Testimonio de Don Leo de Jong Lustig, sobreviviente del Campo de Concentración de Bergen Belsen

Cada uno conoce la sensación de sentir hambre. Perdura hasta que esté saciado. Si no es saciado, sigue el hambre. En realidad no empeora, sino simplemente no cesa. Esto último es lo que hace al hambre tan insoportable. También si se come una vez al día una sopa aguada de nabicol y un pedazo de pan, que mide cuatro centímetros de ancho. Después de esta comida, la sensación de hambre es más ardiente, sobre todo cuando ya le han precedido algunos meses de padecer hambre. Entonces las fantasías de comida son pensamientos que dominan todo. Uno casi no puede pensar en otra cosa. Además te sientes muy débil, porque de verdad estás extremadamente débil. Al tener sed en el desierto se ve una fata morgana. Al tener hambre no se ve nada. Uno piensa exclusivamente en comer. ¡¡Comer. Comer!!

Aparte de que se está débil, tanto que uno a menudo siente que está por desmayarse, se le hinchan los pies; lo llaman edema de hambre. Primero en los tobillos, después en los pies y las piernas. Una de las últimas fases es el edema en la cara. Al principio solamente en las mañanas, más tarde durante todo el día. Como muchacho de catorce años podía entonces hacer un diagnóstico infalible: éste va a durar máximo una semana más. Acertaba siempre. Dentro de una semana el cadáver fue retirado.

En el tiempo que la gente todavía estaba en los primeros estados de estar hambrienta, había todos los días "Appell". Más tarde ya no se podía. Pero durante mucho tiempo sí se podía hacer. Los presos eran contados. Y el número tenía que cuadrar. Con miles de personas, esta no era una tarea fácil. A los adultos se les contaba al irse temprano en la mañana al trabajo, en el "Arbeitsappell". Más tarde nos contaban a nosotros: Los hombres, mujeres y todos los niños que trabajaban o no trabajaban dentro del campo. En seguida los enfermos y 
muertos del día fueron sumados a los que todavía estaban en vida, y este total tenía que cuadrar. Yo creo que nunca cuadraba. Pero de una u otra manera nuestro Lagerälteste griego, Albala, lo hacía cuadrar, lo que no siempre fue aceptado.

El más complicado de los que hacían este inventario era el SS-Oberscharführer Lübbe. Era un hombre delgado, con anteojos de carey, daba la impresión de un amargado maestro de escuela. Su rostro mostraba amargura y odio reprimido. Horas y horas nos dejó parados, a veces días enteros, también cuando estaba helado en la "Lünenburger Heide". El frío mordía nuestros cuerpos agotados. Pero el sentimiento de hambre era más fuerte que el frío y que el dolor en las piernas por estar parado tanto tiempo.

Los presos estaban agrupados según barracas. En el momento que el oficial SS estaba a pocos metros de nuestro grupo, el jefe de la barraca gritaba "Mütze......ab" (Gorros......sacar), lo que todos hacíamos al mismo tiempo. Y entonces llegaba el gran momento. Lübbe contaba las filas de cinco. De vez en cuando cogía una mirada directa de Lübbe.

Curiosamente mi desprecio por este hombre y todos sus colegas estaba mezclado en alguna parte de mí ser con un sentimiento de admiración. Admiración por su falta de humanidad, brutalidad, falta de piedad. Yo experimentaba la misma sensación que se puede sentir al admirar la resistencia de un corredor de larga distancia. ¿Podrá hacer todavía el esfuerzo para la final? o ¿Ya está agotadísimo?

Lübbe tenía resistencia. Si no cuadraba, podía simplemente desaparecer y volver horas más tarde para contarnos de nuevo. Mientras tanto nosotros naturalmente teníamos que quedar parados. ¿Cuánto tiempo más nos dejará parados? A pesar que era nuestro esfuerzo, yo lo admiraba a él por ello. ¿Cómo no hacerlo? Había sólo una respuesta: era un "Übermensch". 
En mí, lo sensacional del Appell venció la sensación del hambre. Agotados volvimos a la barraca. Con el sentimiento que había presenciado un cautivante partido de fútbol. De vuelta a la desolada barraca oliente a sopa de nabo. Extremadamente hambriento, pero de algún modo lleno de admiración por la nueva demostración de crueldad que había podido experimentar...

Leo de Jong Lustig

Escrito en Ramat Chen, Israel, alrededor del año 1971 